\title{
Mapping of perceived dimensions in the bitcoin ecosystem in Brazil
}

\author{
Mapemento das dimensões percebidas no ecossistema de bitcoin no Brasil \\ Roseane Aparecida Almeida Souza Bacharel em Administração. Universidade Federal de São Paulo (UNIFESP) - Brasil. \\ https://orcid.org/0000-0002-2337-8503 sroseane.almeida@gmail.com \\ Luis Hernan Contreras Pinochet Pós-doutor em Administração. Universidade Federal de São Paulo (UNIFESP) - Brasil. \\ https://orcid.org/0000-0003-2088-5283 luis.hernan.@unifesp.br \\ Marcia Carvalho de Azevedo Doutora em Administração. Universidade Federal de São Paulo (UNIFESP). Brasil. \\ https://orcid.org/0000-0002-8368-9637 marcia.azevedo@unifesp.br \\ Evandro Luiz Lopes Pós-doutor em Administração. Universidade Federal de São Paulo (UNIFESP) - Brasil. \\ https://orcid.org/0000-0002-2780-4215 evandro.lopes@unifesp.br
}

\begin{abstract}
Map the dimensions perceived in the bitcoin ecosystem in Brazil. We identified bitcoin dimensions according to the systematic review of the literature from bibliometric analysis. The data collection instrument involved two interview scripts with a qualitative approach and open responses with the participation of 20 interviewees. Collected data was analyzed through content analysis using dimensions and subdimensions of the Bitcoin ecosystem. We identified the dimensions and subdimensions of Brazilian bitcoin network. The dimensions perceived by the actors were Entrepreneurship, Technology, Regulation, and Social. A total of 15 subdimensions were defined. We conducted a cluster analysis of the subdimensions and the interviewees. Results indicated that for our sample all the dimensions had a similar importance. We did not find any significant difference also among the subdimensions because they are all related to each other. We also didn't find significant difference among interviewees. Mapping of the main dimensions and subdimensions of bitcoin network was presented. The study identified that bitcoin as a technology can be effective for many types of organizations such as financial institutions that are losing market share to startups and FinTechs.
\end{abstract}

Keywords: bitcoins; innovation; fintechs; cryptocurrency.

\section{RESUMO}

Mapear as dimensões percebidas no ecossistema de bitcoin no Brasil. Foram identificadas as dimensões do bitcoin de acordo com a revisão sistemática da literatura a partir da análise bibliométrica. $O$ instrumento de coleta de dados envolveu dois roteiros de entrevista com abordagem qualitativa e respostas abertas com a participação de 20 entrevistados. Os dados coletados foram analisados por meio da análise de conteúdo em dimensões e subdimensões do ecossistema Bitcoin. Identificamos as dimensões e subdimensões da rede bitcoin brasileira. As dimensões percebidas pelos atores foram Empreendedorismo, Tecnologia, Regulação e Social. Um total de 15 subdimensões foram definidas. Foi realizada uma análise de cluster das subdimensões e dos entrevistados. Os resultados indicaram que para a nossa amostra todas as dimensões tiveram importância semelhante. Não encontramos nenhuma diferença significativa também entre as subdimensões porque todas são relacionadas entre si. Também não foi encontrada diferença significativa entre os entrevistados. Assim, foi apresentado o mapeamento das principais dimensões e subdimensões da rede bitcoin. $O$ estudo identificou que o bitcoin como tecnologia pode ser efetivo para muitos tipos de organizações como é o caso de instituições financeiras que estão perdendo market share para startups e FinTechs.

Palavras-chave: bitcoin; inovação; fintechs; criptomoedas.

Recebido em 03/04/2021. Aprovado em 08/06/2021. Avaliado pelo sistema double blind peer review. Publicado conforme normas da APA. https://doi.org/10.22279/navus.2021.v11.p01-19.1571

In memory of Luís Augusto Schiavon Ramos 


\section{INTRODUCTION}

The emergence of new Information and Communication Technologies (ICTs) propelled society towards an expansion of network life and consolidated the information age. Today, companies have been forced to focus on innovation to gain and maintain competitive advantage as the only way to adapt and survive. The speed and volatility with which changes occur in the economic environment require an immediate reaction (Feraru, 2017).

From ICT innovations, a new economy emerges, becoming the economy of information and knowledge. The merger of two areas of knowledge - technology, and economics - already made possible to present money in different forms, from magnetic cards to bank transactions via internet; and the most recent proposal for total virtualization of money is presented with bitcoin technology, which is intrinsically linked to blockchain technology.

The advent of bitcoin occurred in 2008, and since then bitcoin code (Nakamoto, 2008) and protocol has boosted innovation in various sectors of economy. Bitcoin is usually associated with the financial sector, because of the word itself, with the suffix coin that remits to currency. But bitcoin is a word that names a type of technology that can be used in many different ways. One example is that bitcoin can be used as investment, without depending on financial institutions and government regulations (Stegaroiu, 2017; Corbet, Lucey, Urqhart, \& Yarovaya, 2019). This new technology works in conjunction with blockchain (Min, 2019), the ledger where all transactions - whether financial or other types of business - are recorded, verifiable and their block chains are cryptographically secured and decentralized (Crosby, Nachiappan, Pattanayak, Verma, \& Kalyyanaraman, 2016), something totally disruptive (Larios-Hernández, 2017; Lee, 2019).

One concern of the market is that bitcoin is highly volatile, and few academic studies seek to explore the dynamics of bitcoin's exchange rate (Lyócsa, Molnár, Plíhal \& Širaňová, 2020). In this sense, the volatility of the bitcoin price can be explained by speculative trade, being seen as a means of investment also speculative (Blau, 2018), due to the trading that is carried out in different time intervals and different currencies (Shynkevich, 2020).

Bitcoin technology is increasingly gaining momentum in applications and the market grows, earning the public's trust, not only through the benefits that technology brings, but by the new way that regulators are looking at this trend. However, the number of people using bitcoin in Brazil is very small compared to current means of payment, financial transactions, and forms of investment. Even though central banks are following its development, robust conclusions on the subject are still missing.

For this technology to constantly grow and gain strength in Brazil, the actors of the bitcoin ecosystem have the mission of disseminating and raising awareness about the issue, so that society has access to its benefits. The insecurity that society has about disruptive technologies is considerable, and this will only be overcome when there is an understanding of the public regarding bitcoin, knowing concepts and the functionality of this new technology (Scharding, 2019).

Also, banks, which are still trying to protect their traditional ways of sending and receiving money, are adapting to the new scenario. In this sense, studies are needed to verify the practice and application of bitcoin, both in financial institutions, and in the segment of the cryptocurrency market.

The theme of bitcoin is increasingly attracting interest and there is a need for more research on the subject, especially in Brazilian context, to help bitcoin be disseminated in the country, like what happened with the advent of personal computer and internet. It is worth clarifying that this research may offer an insight into the perceptions of different groups, that observe the national scenario of the dissemination of bitcoin use as "technology" and as "currency".

Given all the challenges that surround bitcoin, the objective of this research is to map the dimensions perceived in the bitcoin ecosystem in Brazil. Therefore, this study seeks to contribute to the identification of the main dimensions of the bitcoin ecosystem perceived by key actors in this ecosystem and to map the ecosystem perceptions of these dimensions. 


\section{THEORETICAL REFERENCE FRAMEWORK}

\subsection{Bitcoin and entrepreneurship}

The relationship between bitcoin and entrepreneurship exists since the advent of the technology (Chen, 2018). Associated with bitcoin there is a network of entrepreneurs and we can visualize this network in two ways. The first is that each validation point can be considered an entrepreneur (peer-to-peer), as the person carries out the work individually and has gains validating transactions on the blockchain. The second way to visualize entrepreneurship in the bitcoin ecosystem is the new segment that has emerged, the so-called exchanges or bitcoin exchange, mining companies, and technology companies that are based on the blockchain.

Exchanges are online platforms that connect people who want to buy with those who want to sell bitcoins; that is, it is an environment that makes it possible to buy and sell crypto currencies. Exchanges are intermediaries between the two parts and have the role of ensuring that the negotiation process between these two individuals takes place with the greatest possible transparency and security, in which the buyer receives the bitcoins, and the seller receives the money entrusted (Lyócsa et al., 2020).

Sellers make their bitcoins available for sale at the price they want them to be sold, and buyers can buy at the price desired by sellers or place purchase orders looking for offers that meet their price target. The procedure occurs after the interested party performs the registration on the website and sends documents to the exchange company for verification. After the exchange checks and approves the documents, deposits can be made in the currency selected for the purchase of bitcoin.

Although bitcoin transactions on exchanges are anonymous, given that each person is only identified by their "wallet" number, the purchase and sale of bitcoins can be tracked. The user may not even know who they are buying from or who they will be selling to, but each user needs an active CPF (individual tax identification number) to register within the exchange companies. Also, these transactions are made via deposit or bank transfer, which enables financial institutions to know that the user has traded with an exchange company in Brazil. The exchanges can be accessed from the companies' website, or through specific software.

It is important to highlight that these online platforms do not directly sell or buy for their customers, they only manage these connections and profit from the commission per transaction charged by each exchange, that is, the customer just has to search the market looking for exchanges that charge lower commissions.

People who perform direct purchase and/or sale are part of the Brazilian bitcoin community network on social networks or participate in peer-to-peer exchanges. On Facebook, there are several pages about bitcoin and blockchain with thousands of participants. Among the members, there are some people who want to learn about the topic and others who take advantage of the connection between ideas and conversations to carry out buying and selling via chat. For a transaction to happen an individual needs to send the public key for the transfer. In order to improve the security of the transaction the person needs to consider the guidelines given by those who are experienced in this business, such as, for example, look for references, check the user's profile on social networks and in case of a sale, receive the transfer only from the account holder (Scott, Loonam \& Kumar, 2017).

Other means of buying and selling peer-to-peer are operated and maintained by self-programmable software. The program with the interactions is not supervised and managed by an online exchange, an intermediary. The individual pays no commission to anyone; however, the individual is responsible for the transaction as a whole.

All these forms of buying and selling are a way for the individual to be more autonomous in transactions with his money. The importance of entrepreneurship network concerning bitcoin is enormous. This is noticeable when an individual has doubts about how to transact or wants to seek information on how to obtain bitcoins and the network is helpful, offering support to society, through directly or indirectly learning.

Exchanges saw a business opportunity in the field of education and began to design courses for beginners in this ecosystem, explaining everything from key concepts to technical insights into bitcoin 
technology (Lyócsa et al., 2020). In addition to exchanges, many educational institutions were created, focused on the conceptual and financial education of bitcoin.

When society has knowledge about the subject and ways of transacting, and acquires security of what it is transacting, the ecosystem strengthens, the market grows and, consequently, technology develops and tends to become more consolidated. The technology that was used only by a small number of people can reach billions worldwide (Chen, 2018).

The network composed by entrepreneurs of the bitcoin ecosystem has a strong influence on the development of technology. Studies claim that there is an influence of networks in the development of technological capabilities (Tumelero, Sbragia, Borini \& Franco, 2018). It is important to identify the topic of cooperation among entrepreneurs for the continuous improvement of the segment and the improvement of decentralized networks management (Lee, 2019).

\subsection{Bitcoin and technology}

Bitcoin is a form of payment or peer-to-peer commodity with open source, that is not dependent on any central authority. Instead, through its dissemination it has created distributed databases with no central authority responsible - contractually or otherwise - for certifying transfers (Dwyer, 2015). Among other characteristics of bitcoin, what makes it unique is the fact that it is a fully decentralized system (Lee, 2019), sharing information and/or transactions in a unique and universal way for all participating nodes (users) in the world.

Some disagree that bitcoin is a digital currency, as currency must be issued by the government and bitcoin is not; however, the important thing is to be aware that bitcoin is a form of currency, being able to carry out financial transactions in a more practical, fast and effective way. So, the application of blockchain technology to things beyond digital currencies requires new developments in the technology itself (Diedrich, 2016; Chen, 2018).

For Kelly (2013), as a digital currency, bitcoin presents some specific security challenges. If people are not careful, they may inadvertently delete or lose their bitcoins. Once the digital file is lost, money is lost, just like paper cash. Therefore, bitcoin needs cryptographic resources for its protection (Dwyer, 2015).

Another characteristic of bitcoin is mining, which corresponds to the process responsible for maintaining the supply of bitcoin coins, while guaranteeing the integrity and neutrality of the bitcoin network. In other words, mining means verifying if transactions are valid, and consequently, whether they should be inserted in a valid block chain. In this way, the mining concept creates a competitive environment that prevents anyone from easily adding new blocks consecutively in the blockchain (Min, 2019).

Like all new disruptive technology, bitcoin is a source for criticism and concerns, especially when there are paradigm changes, for example, regarding the use of banking services. Society worries about the security and solidification of the asset; however, bitcoin has revolutionary advantages, allowing the individuals to make their own choices, at the right time, and without high fees.

Bitcoin technology development and operation present advantages and opportunities for specific niches, but it also has disadvantages and points that must be improved. The dissemination of bitcoin promotes a discussion that particularly impacts our country, due to the high interest rates and bank rates in Brazil. It is important to note that there is no control over assets in bitcoin, which are at the mercy of the arbitrariness of speculators, given the high volatility of their prices for other currencies. The determination of the value of the virtual currency may be impaired, as it does not constitute an organized market with liquidity and wider use. In addition to exchanges, businesses are being created using the bitcoin protocol for bitcoin debit cards; online shopping; international P2P loans; micropayments; digital notaries, donations; among others.

\subsection{Bitcoin and regulation}

The advent and usability of bitcoin have presented a major challenge to legal systems not only in Brazil, but worldwide, since there are countries that have specific regulations for cryptocurrencies, others that have banned their commercialization, and even governments that have not specific regulations for 
cryptocurrencies. This is due to the new paradigms generated and ways of using this disruptive innovation (Larios-Hernández, 2017).

Bitcoin circulation and trade in Brazilian territory are legal; however, it does not have a specific regulation like some countries in the world. Some companies accept bitcoin as a form of payment in the country, however, there are no normative regulations for this matter, that is, even if bitcoins are accepted as a means of exchange by institutions and organizations, there is no particular accounting guidance for these types of transactions (Andrade, 2017).

Tax authorities and law enforcement agencies seek to understand the technology and apply existing regulatory models to this innovation. This application will depend on the territory in which this means of payment is being used, since some countries recognize it as an asset, other as currency, commodities, or a form of payment (Corbet et al., 2019).

Despite the lack of regulation for bitcoin, there are laws and communications from the Brazilian National Central Bank (Bacen) that direct it to future regulation in Brazil, these being, Bacen Communication $n^{\circ} 25.306$ of February 2014, Bill 48/2015 that aims to extinguish cash, Bill No. 2303/2015, and taxes collection by the Brazilian IRS on the acquired virtual currencies transactions.

"Electronic currencies" addressed in Law no 12.865, of October 9, 2013, with its infra legal regulation, are not synonymous with virtual or encrypted "currencies", since electronic currencies are the digital money issued by the Central Bank and the encrypted currency depends on network users to use an algorithm for its generation, being decentralized (Lee, 2019) and its issue not being defined by politicians (Albuquerque \& Callado, 2015).

In addition, Law no 12.865 (2013), establishes rules for international payment arrangements, to give support to external operations, necessary for any increasingly open economy integrated with international markets. For this reason, there is no need to create additional specific legal rules to support transactions in electronic media using dollars, euros, air miles points, or bitcoins. In addition, the law itself establishes that only payment arrangements that may have systemic importance should be regulated. As stated earlier, bitcoin is not large enough, or systemically relevant as a means of payment, to be currently subject to Bacen regulation.

Another bill that gives evidence that the number of bitcoin users can increase after its approval, is the bill number $48 / 2015$, that aims to extinguish the production, circulation, and use of cash, and imposes that financial transactions happen only through the digital system (Câmara dos Deputados, 2015a).

It is possible that in a future scenario there will be an increase of use of electronic coins at first; however, with the high fees and taxes that are also applicable to cash nowadays, users will already know how to deal with electronic currencies and will be more interested in using other forms of payment with encrypted currencies such as bitcoin, as these are more flexible, agile, without taxes on issuance or withdrawal, and decentralized (Corbet et al., 2019; Lee, 2019).

Bill $n^{\circ} 2303$, of 2015 , provides the lay out for the inclusion of virtual currencies and air mileage programs in the definition of "payment arrangements" under the supervision of the Central Bank (Câmara dos Deputados, 2017). With the approval of this bill, item I of art. 9 of Law 12.865/2013 will be modified and $\S 4$ to article 11 of Law 9.613, of March 3, 1998 will be added: "Art. 11 (...) § 4 The operations mentioned in item I include those involving virtual currencies and air mileage programs". The status of this bill is in progress since after approval of the request, it requires a public hearing to discuss the effects of new technologies, blockchain, and cryptocurrencies, with a bias towards payments (Câmara dos Deputados, 2015b).

Even if the purchase and sale of products and services with bitcoin are not taxed (since the currency is not regulated by any country), the purchase and sale of bitcoin for tax purposes must be declared as assets in the individual income tax. The emergence of this form of payment has enabled a new form of enterprise in the country: the exchanges described in the topic "Bitcoin and Entrepreneurship". Startups help disseminate knowledge about bitcoin technology and because they have expertise on the subject, they are called upon to discuss bills, giving greater credibility to government officials.

In general, financial institutions, faced with the fast changes that occur in the crypto currency market, need to follow the needs of their consumers and present efficient solutions. Even with the current competition 
between banks and FinTechs, the vast majority of banks already predicted that these technology companies would impact the financial landscape and almost a third of them imagined that FinTechs would have a good market share.

Even with the growth of startups, the regulation of bitcoin is something that bothers not only users, but the whole society that does not understand the technology and seeks to study and comprehend how this means of payment works. The insecurity of the population when it comes to obtaining and using cryptocurrency means that Brazil is not a reference for users. The trend is followed by regulators such as the Federal Revenue Service and the Brazilian National Central Bank, which are positioning themselves by issuing statements on the legal nature of cryptocurrencies (Roberto, Horta, Luz \& Monteiro, 2017).

As the number of bitcoin users in the country is small and its spread in the domestic economy is not relevant, Brazilian National Central Bank declared to be following the growth of the national market, discussions in international forums mainly regarding its nature, ownership, and operation. In countries like Germany, United States and Australia the technology already has some type of regulation. However, Brazilian actors in bitcoin environment affirm it is not coherent to copy the regulation from abroad, but it is necessary to make an appropriate regulation for the reality of Latin America (Deliberative Meeting, PL2303/15).

In the traditional financial system, money is obtained in exchange for products or services. The same is true in the bitcoin system. To receive cryptocurrencies, the user must contribute to the completion of transactions by offering their processing capacity.

Since bitcoin has a restricted reach in the country, there is no perceived systemic risk for the continued commercialization and circulation of cryptocurrency in the domestic economy. However, the topic is much more discussed in the scope of money laundering, mainly by the country's major banks, which are increasingly adapting to these technologies and have concerns about illegal international activities.

\subsection{Bitcoin and society}

Technology has always been transforming society and since internet was launched the speed of change has increased dramatically, presenting society with new ways of interaction and communication. With internet, the user not only started to obtain more access to information, but began to use new ways for, for example, carry out financial transactions in a faster, more effective, and less bureaucratic way, which makes life a lot easier for people in general. People's preference for using credit cards or making online transactions are examples of an expansion of network life, consolidating the information age.

The degree of freedom of expression increased with the advent of the internet, since internet use makes easier for human beings to express their thoughts and act according to their needs and personal rules. Even authoritarian and totalitarian states are not able to change these internet characteristics.

The adoption of bitcoin technology by users in the country is difficult, as population in general has a lack of understanding of what bitcoin is and how it works, besides there is a lack of tools that simplify the understanding, so that older people, for example, can understand what happens in this decentralized network (Lee, 2019). Most of the time bitcoin ends up being seen as something illegal, being applied for money laundering and this view impairs the adoption by potential users.

There are several ways to obtain bitcoins. Primary production takes place through the mining process, which requires a high and ceaseless processing power from the miner in the grid made with electricity. From the point of view of energy expenditure, mining can cause environmental problems, due to the superpower machines with high hardware development that are used to carry out the mining process.

Other ways of obtaining bitcoin are through buying on exchanges, buying directly from another user, and also receiving the value in bitcoins through a sale of goods or provision of services. In spite of the increase in the number of digital currency adepts in the country, there are many users who remain doubtful and skeptical about its application. This is due to the currency's instability, that suffers a lot of fluctuation in its price that comes from the supply and demand of currency by users. There is no long-term forecast of values with bitcoin and, consequently, using it as an investment medium is indicated for more aggressive investment profiles, as it is considered a high-risk investment. 
The possibility to apply a new technology worldwide and the potential of a new technology to rise the quality of life are not common characteristics. One reason to say that bitcoin can improve quality of life is its deflationary characteristic; so, using a currency that cannot be inflated by the government, and that tends to maintain its purchasing power, is already an excellent tool against poverty. Another example would be transfers of money for donation to NGOs that pay fees in the same way as any other financial transaction, that is, the donation will never reach the amount that the donor sent, it will always be less. With bitcoin, the value is fully received, with no transition fees.

Also, bitcoin has an inclusive power to a population that is unable to have access to traditional financial institutions because of the bank fees. From that, bitcoin has the potential to solve problems of a layer of the poorest population or regions more distant from the metropolises, where access to the banking system is almost nonexistent or very precarious, and which currently, is practically on the margin financial and banking systems. Furthermore, this technology is present not only in financial transaction services, but also in authentication and patent services (Diedrich, 2016; Min, 2019), among others.

\section{METHOD}

In this context, a gap was identified, due to the lack of studies investigating the theme in Brazil - since it is recent and benefits, opportunities and best practices adopted by other countries are still being identified. The research had as a method the use of exploratory bibliometric analysis of publications on the theme of bitcoin. Bitcoin was created in 2008 and its commercialization as currency began in middle of 2010, opening space for scientific publications on the subject. Based on this, we decided to review articles published from 2011 until the time of data collection. Using the word "Bitcoin" as a filter we searched papers with peer review, published between 2011 and 2020 in the Web of Science (WoS) database. A total of 884 papers were found in 25 of the 39 categories of the database, 6 of these categories were interdisciplinary or multidisciplinary. We read the titles and identified 4 dimensions that the theme bitcoin is discussed: business and entrepreneurship, technological aspects, law and regulation and social environment. The next step was the classification of the 25 categories and the papers on the 4 dimensions of bitcoin discussion. The classification is presented in Table 1.

\begin{tabular}{ccc}
\hline Bitcoin Dimensions & \# of WoS Categories & \# of Papers \\
\hline Business and Entrepreneurship & 4 & 447 \\
Technological Aspects & 11 & 256 \\
Law and Regulation & 2 & 26 \\
Social Environment & 2 & 16 \\
Interdisciplinary and Multidisciplinary & 6 & 139 \\
\hline Total & 25 & 884 \\
\hline
\end{tabular}

Table 1. Classification of Web of Science categories of published papers

Source: Research data (2021).

Most of the papers are published discussing bitcoin business and also entrepreneurship aspects. It is expected as bitcoin has a huge impact on established business models of many organizations and economic segments. It has also attracted the interest of a lot of entrepreneurs. The second dimension with more papers is related with technological aspects, as bitcoin is a disruptive and very new technology. Law and regulation and social environment aspects have also been discussed. There are less papers discussing these dimensions, but they are extremely important, since bitcoin and its disruptive characteristics require and need an adequate legal environment. Social aspects are also central to be addressed due to its potential in the promotion and support of a more inclusive society.

Content analysis was used with the support of NVivo Pro. The focus of this study is bitcoin innovation ecosystem from a business perspective, to address the focus we selected fields of studies involving "Business", "Business Finance" and "Management" (Table 2). Papers were identified, as well as the respective citations, in addition to the most influential authors. This helped to identify which citations would be appropriate to be 
used to support each of the four areas used in this research as guidelines for the development of the research instrument.

\begin{tabular}{lccc}
\hline \multirow{2}{*}{ Bitcoin Dimensions } & \multicolumn{3}{c}{ Fields } \\
\cline { 2 - 4 } & Business & Business Finance & Management \\
\hline Business and Entrepreneurship & 8 & 0 & 7 \\
Technological Aspects & 38 & 34 & 29 \\
Law and Regulation & 20 & 49 & 13 \\
Bitcoin and Society & 17 & 5 & 13 \\
\hline \multicolumn{1}{c}{ Total } & 83 & 88 & 62 \\
\hline
\end{tabular}

\section{Table 2. Number of citations per field}

Source: Research data (2021).

Web of Science database was used, and some filters were applied, such as "full text", document type - "article", English language, years "2011-2020", through the terms "bitcoin business and bitcoin entrepreneurship" (business and entrepreneurship), "bitcoin technology" (technological aspects), "bitcoin regulation" (law and regulation), "bitcoin and society" (social environment) (Table 3).

\begin{tabular}{|c|c|c|c|c|c|c|c|c|c|c|c|c|}
\hline \multicolumn{2}{|l|}{ Dimensions } & 201 & 201 & 201 & 201 & 201 & 201 & 201 & 201 & 201 & 202 & Tota \\
\hline & & 1 & 2 & 3 & 4 & 5 & 6 & 7 & 8 & 9 & 0 & I \\
\hline $\begin{array}{c}\text { Bitcoin Business } \\
\text { and }\end{array}$ & $\begin{array}{l}\text { Publishe } \\
\text { darticles }\end{array}$ & 0 & 0 & 0 & 0 & 0 & 0 & 0 & 2 & 0 & 8 & 10 \\
\hline $\begin{array}{l}\text { Entrepreneursh } \\
\text { ip }\end{array}$ & $\begin{array}{l}\text { Sum of } \\
\text { Time }\end{array}$ & & & & & & & & & & & \\
\hline $\begin{array}{c}\text { (WoS: } \\
\text { "Entrepreneur*" }\end{array}$ & Cited & 0 & 0 & 0 & 0 & 0 & 0 & 0 & 3 & 20 & 52 & 75 \\
\hline \multicolumn{13}{|l|}{$\begin{array}{l}\text { "Entrepreneur*" } \\
\text { AND "bitcoin") }\end{array}$} \\
\hline $\begin{array}{l}\text { Bitcoin } \\
\text { Technology }\end{array}$ & $\begin{array}{l}\text { Publishe } \\
\text { d articles }\end{array}$ & 0 & 0 & 0 & 0 & 3 & 0 & 7 & 14 & 28 & 36 & 88 \\
\hline $\begin{array}{l}\text { "Techno*" AND } \\
\text { "bitcoin") }\end{array}$ & $\begin{array}{l}\text { Time } \\
\text { Cited }\end{array}$ & 0 & 0 & 0 & 0 & 2 & 9 & 26 & 64 & 245 & 373 & 719 \\
\hline \multirow{2}{*}{$\begin{array}{c}\text { Bitcoin } \\
\text { Regulation } \\
\text { (WoS: "Regula*" } \\
\text { AND “bitcoin") }\end{array}$} & $\begin{array}{l}\text { Publishe } \\
\text { d articles }\end{array}$ & 0 & 0 & 0 & 2 & 1 & 4 & 7 & 14 & 19 & 28 & 75 \\
\hline & $\begin{array}{l}\text { Sum of } \\
\text { Time } \\
\text { Cited }\end{array}$ & 0 & 0 & 0 & 0 & 0 & 0 & 4 & 21 & 123 & 271 & 419 \\
\hline $\begin{array}{l}\text { Bitcoin and } \\
\text { Social }\end{array}$ & $\begin{array}{l}\text { Publishe } \\
\text { d articles }\end{array}$ & 0 & 0 & 0 & 0 & 0 & 0 & 3 & 7 & 11 & 10 & 31 \\
\hline $\begin{array}{l}\text { Environment } \\
\text { (WoS: "Social*" } \\
\text { AND "bitcoin") }\end{array}$ & $\begin{array}{l}\text { Sum of } \\
\text { Time } \\
\text { Cited }\end{array}$ & 0 & 0 & 0 & 0 & 0 & 0 & 5 & 21 & 76 & 106 & 208 \\
\hline \multirow[b]{2}{*}{ Total } & $\begin{array}{l}\text { Publishe } \\
\text { d articles }\end{array}$ & 0 & 0 & 0 & 0 & 0 & 0 & 17 & 37 & 58 & 82 & 204 \\
\hline & $\begin{array}{l}\text { Sum of } \\
\text { Time } \\
\text { Cited }\end{array}$ & 0 & 0 & 0 & 0 & 0 & 0 & 35 & 109 & 464 & 802 & $\begin{array}{c}142 \\
1\end{array}$ \\
\hline
\end{tabular}

Table 3. Number of published articles and sum of citations in the period

Source: Research data (2021).

When we analyzed only the articles published in Web of Science and tried to find relationships between them, we observed (Table 3) that in the dimension "Bitcoin Business and Entrepreneurship", few articles published in recent years in the selected fields were identified $(n=10)$. Chen $(2018)$ is the most cited 
$(n=56)$ in addition to having greater strength in the network $(n=6)$, there are other authors, however, the distance from the relevance of the work that leads the ranking is notorious. When we analyze the "Bitcoin Technological Aspects" dimension, the article by Dwyer et al. (2015) is said to be the most cited ( $n=177)$, being also the author with greater strength in reaching the network $(n=37)$. Other authors whose citations stand out are Chen (2018) $(n=56)$ and Min (2019) (44), as well as Lee (2019) ( $n=13)$ and Chen (2018) $(n=12)$. When analyzing the "Bitcoin Law and Regulation" dimension, we noticed that the most cited authors ( $n=99)$ had also the greater strength in the network ( $n=43)$, they are Corbet et al. (2019). Finally, in the "Bitcoin and Social Environment" dimension, the authors Scott et al. (2017) appear first in both classifications with the highest citation ( $n=35)$, as well as greater strength in the network $(n=2)$ in relation to others.

Due to the small number of empirical studies developed on factors relevant to the mapping of dimensions in the bitcoin ecosystem, a field research with a qualitative approach was designed, to identify relevant dimensions in the national bitcoin cryptocurrency market.

The study with a qualitative approach, was based on the proposed objectives, and obtained information through the use of a research script. The qualitative research results from the semi-structure interviews conducted with the use of the script.

The most reliable way to apply a survey to chains of reference is when you obtain the maximum amount of information from all members of the network or when you use a random sample of network participants. However, sometimes this method is not feasible, and the snowball technique (non-probabilistic) can be more feasible (Vinuto, 2014).

The field research had two stages. In the first stage, a mapping was carried out in groups of participants in social networks (where there is a greater concentration of people with expertise in the subject), to select subjects who could be volunteers to be interviewed.

In the second stage, primary data was collected with the selected sample (lawyers, administrators, executives, users, and others). The sample was composed of people who were part of a group on Facebook called "Bitcoin Brazil" with thousands of members that interact with the main players in the bitcoin market. The main exchange companies in Brazil were formed through this group. The relationships in this environment are very direct (which proves the peer-to-peer relationship) and the players are very helpful regarding the doubts of newcomers in the segment.

This research sought to understand relationships between the main actors, compare ideals, and bring together connected thoughts. The analysis was based on perceptions of respondents and a software was used to organize the data.

The content analysis is a tool for understanding the meaning that research subjects externalized in the discourse. This allowed the researcher to comprehend the individual representations about his experiences and perceptions. In the next step, the data collected needed to be organized. The numerical form of data presentation makes possible to conduct the analyzes with the help of statistical instruments.

For recording the interviews, the Free Video Call Recorder for Skype software was used, and the transcription was performed manually. The information was organized by NVivo software.

Cluster analysis were conducted using NVivo to explore relationships among interviewees and also among subdimensions of bitcoin ecosystem. The cluster analysis was performed based on Pearson correlation and the results were represented by a dendrogram.

\section{Instrument for data collection}

The data collection instrument used in the semi-structured interview was developed based on bitcoin dimensions discussed in several published studies (Table 4). 


\begin{tabular}{|c|c|c|}
\hline $\begin{array}{l}\text { BITCOIN } \\
\text { DIMENSION }\end{array}$ & QUESTIONS & REFERENCES \\
\hline $\begin{array}{l}\text { Business and } \\
\text { Entrepreneurship }\end{array}$ & $\begin{array}{l}\text { What made you start a business? } \\
\text { Which entrepreneurs inspired you? } \\
\text { Was anyone in your family an entrepreneur? } \\
\text { Was there a "trigger" event to start the business? } \\
\text { Did you create your business during college / } \\
\text { high school? } \\
\text { How did you evaluate the opportunity? } \\
\text { Did you have a business plan? Did you have any } \\
\text { kind of planning? Ask for explanations. } \\
\text { What is your formal education? Was it relevant to } \\
\text { the business? } \\
\text { What previous work experience did you have } \\
\text { before opening the business? } \\
\text { What are your strengths and weaknesses? } \\
\text { Did you have a partner? } \\
\text { Did your partners complement your skills to } \\
\text { move the business forward? } \\
\text { What resources (economic/financial) did you } \\
\text { need to implement the business? } \\
\text { Where and how did he obtain these resources? }\end{array}$ & $\begin{array}{c}\text { Andrade (2017) } \\
\text { Feraru (2017) } \\
\text { Filion (1999) } \\
\text { Henderson (1989) } \\
\text { Stegaroiu (2017) }\end{array}$ \\
\hline $\begin{array}{l}\text { Technological } \\
\text { Aspects }\end{array}$ & $\begin{array}{l}\text { What are the advantages of Bitcoin protocol } \\
\text { technology? } \\
\text { What are Bitcoin's main technological } \\
\text { challenges? } \\
\text { Users called "miners" are rewarded for their work } \\
\text { with newly created bitcoins. What are the main } \\
\text { challenges and future opportunities for this } \\
\text { group of individuals who, based on } \\
\text { computational strength, perform transaction } \\
\text { records, and reconciliations? } \\
\text { Can mining bitcoins cause environmental } \\
\text { problems? } \\
\text { How does bitcoin mining make it possible to } \\
\text { maintain Bitcoin's security? } \\
\text { What will be other opportunities for using the } \\
\text { Bitcoin protocol for the market? }\end{array}$ & $\begin{array}{l}\text { Dwyer (2015) } \\
\text { Chen (2018) } \\
\text { Min (2019) } \\
\text { Lee (2019) } \\
\text { Pires (2017) }\end{array}$ \\
\hline Law and Regulation & $\begin{array}{l}\text { Can Bitcoin be considered an international "new } \\
\text { currency"? Explain. } \\
\text { Will Bitcoin be able to reshape the monetary } \\
\text { system? } \\
\text { Will there be possible interventions? } \\
\text { Will there be possible regulations? } \\
\text { Will there be taxes? } \\
\text { What are the possible attempts at control? } \\
\text { Bitcoin made possible the emergence of new } \\
\text { businesses like Exchanges, what are the legal } \\
\text { requirements and/or authorizations for this type } \\
\text { of company to work? How are these companies } \\
\text { seen by banks? } \\
\text { Regarding the legal aspects of bitcoin, how does } \\
\text { consumer protection occur? }\end{array}$ & $\begin{array}{c}\text { Corbet et al. (2019) } \\
\text { Lee (2019) } \\
\text { Roberto et al. (2017) }\end{array}$ \\
\hline Social Environment & $\begin{array}{l}\text { Should Exchange companies last in the market, } \\
\text { or is there a potential competitor in another }\end{array}$ & $\begin{array}{c}\text { Pires (2017) } \\
\text { Scott et al. (2017) } \\
\text { Tumelero et al. (2018) }\end{array}$ \\
\hline
\end{tabular}


sector that could become a new entrant, thus developing aspects of competition?

What types of businesses would be doomed to disappear in the coming years with the intense use of Bitcoin?

What are Bitcoin's main social challenges? What is the relationship between Bitcoin and human freedom?

Can mining bitcoins cause environmental problems?

What will be other opportunities for using the Bitcoin protocol for the market?

Recent research shows that Bitcoin has the potential to improve the quality of life, as a potential weapon against poverty and oppression. Cite practical examples and possibilities.

\section{Table 4. Dimensions with their respective questions}

Source: Research data (2021).

Table 5 presents the information of the 20 interviewed that were part of the sample.

\begin{tabular}{|c|c|c|c|c|c|c|c|}
\hline Code & $\begin{array}{c}\text { Intervie } \\
\text { w } \\
\text { (min.) }\end{array}$ & $\begin{array}{c}\text { \# of } \\
\text { pages }\end{array}$ & $\begin{array}{c}\text { \# of } \\
\text { words }\end{array}$ & Age & $\begin{array}{c}\text { Compan } \\
y \\
\text { location }\end{array}$ & $\begin{array}{c}\text { Business } \\
\text { (company) }\end{array}$ & Key position \\
\hline E01 & 53.03 & 15 & 5824 & 20 & $\begin{array}{c}\text { São } \\
\text { Paulo }\end{array}$ & Exchange & $\mathrm{COO}$ \\
\hline E02 & 50.44 & 16 & 6520 & 32 & $\begin{array}{l}\text { São } \\
\text { Paulo }\end{array}$ & $\begin{array}{c}\text { Digital } \\
\text { services } \\
\text { provider } \\
\text { (technology } \\
\text { ) }\end{array}$ & CEO \\
\hline E03 & 94 & 21 & 9522 & 42 & $\begin{array}{l}\text { São } \\
\text { Paulo }\end{array}$ & $\begin{array}{c}\text { Digital } \\
\text { services } \\
\text { provider } \\
\text { (technology } \\
\text { ) }\end{array}$ & $\begin{array}{c}\text { Individual } \\
\text { Entrepreneu } \\
r\end{array}$ \\
\hline E04 & 42.32 & 12 & 4616 & 28 & Recife & $\begin{array}{l}\text { Payment's } \\
\text { operator }\end{array}$ & CEO \\
\hline E05 & 104.49 & 30 & 15609 & 44 & $\begin{array}{l}\text { São } \\
\text { Paulo }\end{array}$ & $\begin{array}{c}\text { Provider of } \\
\text { digital } \\
\text { services } \\
\text { (technology } \\
\text { ) }\end{array}$ & CEO \\
\hline E06 & 109.36 & 29 & 13179 & 24 & $\begin{array}{l}\text { São } \\
\text { Paulo }\end{array}$ & Exchange & CEO \\
\hline E07 & 104.24 & 27 & 13412 & 35 & $\begin{array}{l}\text { Nova } \\
\text { York }\end{array}$ & $\begin{array}{c}\text { Digital } \\
\text { services } \\
\text { provider } \\
\text { (technology } \\
\text { ) }\end{array}$ & CEO \\
\hline E08 & 133.32 & 41 & 19838 & 27 & $\begin{array}{l}\text { Rio de } \\
\text { Janeiro }\end{array}$ & $\begin{array}{c}\text { Educational } \\
\text { service } \\
\text { provider }\end{array}$ & Coordinator \\
\hline
\end{tabular}




\begin{tabular}{|c|c|c|c|c|c|c|c|}
\hline E09 & 85.24 & 20 & 9822 & 36 & Macapá & $\begin{array}{c}\text { IT } \\
\text { professional }\end{array}$ & $\begin{array}{c}\text { Individual } \\
\text { Entrepreneu } \\
r\end{array}$ \\
\hline E10 & 89.59 & 13 & 8057 & 25 & $\begin{array}{l}\text { São } \\
\text { Paulo }\end{array}$ & $\begin{array}{c}\text { Autonomou } \\
\mathrm{s}\end{array}$ & Lawyer \\
\hline E11 & 94.95 & 23 & 10274 & 30 & $\begin{array}{l}\text { São } \\
\text { Paulo }\end{array}$ & $\begin{array}{c}\text { Payment's } \\
\text { operator }\end{array}$ & CEO \\
\hline E12 & 60.74 & 16 & 6191 & 32 & $\begin{array}{l}\text { São } \\
\text { Paulo }\end{array}$ & Exchange & CEO \\
\hline E13 & 63.33 & 17 & 6686 & 36 & Curitiba & Exchange & CEO \\
\hline E14 & 55.54 & 15 & 7029 & 45 & Brasília & $\begin{array}{l}\text { Public } \\
\text { servant }\end{array}$ & $\begin{array}{l}\text { Adm. } \\
\text { Bitcoin } \\
\text { group }\end{array}$ \\
\hline E15 & 64.08 & 16 & 6533 & 35 & Aracaju & $\begin{array}{c}\text { Educational } \\
\text { service } \\
\text { provider }\end{array}$ & CEO \\
\hline E16 & 49.86 & 13 & 4504 & 41 & $\begin{array}{l}\text { São } \\
\text { Paulo }\end{array}$ & Exchange & CEO \\
\hline E17 & 44.04 & 12 & 4105 & 26 & Curitiba & $\begin{array}{c}\text { News } \\
\text { website }\end{array}$ & CEO \\
\hline E18 & 110.34 & 27 & 11460 & 37 & $\begin{array}{l}\text { São } \\
\text { Paulo }\end{array}$ & $\begin{array}{c}\text { Digital } \\
\text { services } \\
\text { provider } \\
\text { (technology } \\
\text { ) }\end{array}$ & CEO \\
\hline E19 & 45.31 & 12 & 5245 & 42 & Recife & $\begin{array}{c}\text { Digital } \\
\text { services } \\
\text { provider } \\
\text { (technology } \\
\text { ) }\end{array}$ & CEO \\
\hline E20 & 34.21 & 9 & 3440 & 35 & $\begin{array}{l}\text { São } \\
\text { Paulo }\end{array}$ & $\begin{array}{c}\text { Autonomou } \\
\mathrm{s}\end{array}$ & Economist \\
\hline $\begin{array}{l}\text { Sum } \\
\text { verage }\end{array}$ & $\begin{array}{c}1488.4 \\
74.42 \\
\end{array}$ & $\begin{array}{l}384 \\
19.2 \\
\end{array}$ & $\begin{array}{l}171866 \\
8593.3 \\
\end{array}$ & $\begin{array}{c}- \\
33.6 \\
\end{array}$ & $\begin{array}{l}- \\
-\end{array}$ & - & - \\
\hline
\end{tabular}

Table 5. Sample Information

Source: Research data (2021).

There was a total of 24.4 hours of interview, with an average of 74.42 minutes for each interviewee. There was a total of 384 pages with the transcription of all the 20 interviews. The survey kept the identification of the interviewees anonymous, preserving integrity.

\section{NVivo software}

The content of the interviews was grouped using the NVivo11Pro software. The use of this software was of great importance for the analysis of our research because it allowed an analysis of the interviews transcribed in a structured and organized way (Lage \& Godoy, 2011). The software facilitated the organization of interviews and categorization of data and analyzes. Interviews were coded in the 4 bitcoin dimensions and sub-dimensions in each dimension were developed based on interview content. NVivo software was also use to perform cluster analysis based on Pearson Correlation of the interviewees and bitcoin subdimensions.

\section{Unit of analysis}

The sample of 20 interviewees (Table 5) was obtained using the snowball technique. Initially, the main idea was to analyze the opinion of key informants of exchange companies in the bitcoin segment. More and more people are interested in understanding how bitcoin technology works. The "Bitcoin Brazil" group despite disagreements between administrators and members - has a significant number of active members. 
The CEOs of each of the main exchanges operating in the national market were contacted and invited to be part of the sample. Unfortunately, not everyone was available to give interviews at first.

When starting the interviews, it became clear that many questions were addressed to other players who had specific knowledge on the subject, and who could contribute with other perspectives, in addition to the exchange itself. So, we identified the main segments and other relevant players in the bitcoin ecosystem, and agents that contribute with the bitcoin financial market were also included in the sample. Within each segment, individuals with general knowledge were selected.

Individuals interviewed worked in different type of business, like exchanges, service providers related to bitcoin (educational, news, and digital platforms), payment operators. We also interviewed individuals who do not have a work in a business directly, however, they have significant knowledge on the subject, such as lawyers, economists, IT professionals and traders (Table 6).

\begin{tabular}{cc}
\hline Companies / Autonomous & \# of interviews \\
\hline Exchange & 5 \\
Service providers (Bitcoin in general, & 8 \\
digital, educational and news) & 2 \\
Payment operators & 5 \\
Others & 20 \\
\hline Total
\end{tabular}

Table 6. Sample of people contacted

Source: Research data (2021).

\section{RESULTS AND DISCUSSION}

\subsection{Bitcoin dimensions and subdimensions}

Dimensions resulted from the analysis of the published papers related to bitcoin. The 15 subdimensions, on the other hand, emerged from the analysis of the transcripts of the interviews.

\section{Dimension: Bitcoin Business and Entrepreneurship}

This dimension refers to the businessmen and entrepreneurs interviewed who work in the bitcoin segment. Because bitcoin technology is disruptive and extremely recent, most of the players operating in the market are entrepreneurs. Identifying what are the common characteristics among them and understanding their perspectives on the topic brings us a broader comprehension of bitcoin business environment (Table 7) (Andrade, 2017; Feraru, 2017; Filion, 1999; Henderson, 1989; Stegaroiu, 2017). Interviewees discussed specific aspects of the dimension, and the analysis of the main themes gave origin to subdimensions.

\footnotetext{
Influence is the fact that you rely on other experiences to make decisions. One Influence factor that can indirectly influence the decision to open a company is the existence of reference models.

Organizational Strategy is, from an emerging perspective, the use of imagination and logic to strategy respond to the environment in such a way that a competitive advantage for the company is generated as a result.

Start of the entrepreneurial process The entrepreneurial process involves identifying and evaluating the opportunity, developing the business plan, determining and raising the necessary resources and, finally, managing the company created.

The threat of substitutes is when different services and products offered by rival

Substitute product companies satisfy the same needs of customers, but in a different way. Substitutes impose a limit on a firm's prices, which could lower its earnings.
} 
Resources

Society

Professional life
Organizational Resources are the various means that institutions have to achieve their objectives. These are the goods or services used in organizational activities. When it comes to resources, we are not only referring to money, but we are referring to the raw materials used in production, in the services provided by organizations, materials, equipment, and employees.

Entrepreneurial Society is one that professionally carries out an organized economic activity for the production or circulation of goods or services, constituting a company element.

It is, in fact, about studying the path of a person in an organization (or a series of organizations) and also understanding how that person's characteristics influence the organization and are, at the same time, influenced by it.

Table 7. Subdimensions of Bitcoin Business and Entrepreneurship

Source: Research data (2021).

Dimension: Bitcoin Technological Aspects

This dimension refers to all cryptographic construction that is behind bitcoin - a form of payment. It is important to note that bitcoin technology differs from means of payment and/or commodities since there is a structure that supports bitcoin. Encryption is not a new technology; it is used in various services of our day-today as in the protection of websites and applications. It guarantees the security of bitcoin, making it impossible for a user to take possession of another user's wallet and prevents the blockchain from being breached and corrupted, ensuring information integrity and safety (Table 8) (Dwyer, 2015; Chen, 2018; Min, 2019; Lee, 2019; Pires, 2017). Subdimensions were also developed for this dimension.

Blockchain

Mining

Bitcoin protocol
Distributed database, it is online, public and can be updated by any node participating in the peer-to-peer network (P2P). It is based on the consensus between participants and ensured by a Proof-of-Work algorithm. Mining is the process responsible for maintaining the supply of bitcoin coins while guaranteeing the integrity and neutrality of the bitcoin network. Byzantine consensus protocol based on cryptographic challenges, opensource software, which is based on a decentralized computer network (peerto-peer).

Table 8. Subdimensions of Bitcoin Technological Aspects

Source: Research data (2021).

Dimension: Bitcoin Law and Regulation

This dimension refers to legal environment of bitcoin, as well as its circulation and trade in the country. It is known that in Brazil there is no specific regulation, and because of that the market is not consolidated enough to institute a legislation that is adequate to deal with electronic currencies environment. However, the regularization of bitcoin would be ideal, so that there would no gray legal zones due to the application of the law when problems happen, like in trade transactions, or even loss of this commodity (Table 9) (Corbet et al., 2019; Lee, 2019; Roberto et al., 2017). The dimension was divided in 4 subdimensions. Exercise of activity requirements, remaining active in the market, and providing services to their customers.

Legal issues Refers to the development or the existence of legal terms within the scope of the digital currency.

Monetary system Refers to the change in the financial view that Bitcoin technology causes.

Control attempts

Refers to the means or ways of dealing with a specific company (with fees, laws, among others) that threatens the government.

Table 9. Subdimensions of Law and Regulation

Source: Research data (2021).

Dimension: Bitcoin and Social Environment 
This dimension refers to social aspects in which bitcoin, as a form of payment and technology, interferes and influences the digital transformation of postmodern society. There are great challenges to be faced with the development of this new technology; however, moving towards a more just and egalitarian society is possible through this innovation. Relating society to the financial system, the social body is so used by the State monetary systems to make the connection of a currency with the government, that the presentation of a decentralized network where the individual is the owner of his own money, can move it at any time, and is not dependent on third parties, changes the global financial system in a revolutionary way. Such an embracing change generates distrust among possible users, which might lead to the disuse of the technology by conservative profiles, as well as induce the adoption of the knowledge by more aggressive profiles (Table 10) (Pires, 2017; Scott et al., 2017; Tumelero et al., 2018). The Social Environment dimension has 5 subdimensions.

Social competition in the provision of services

Adoption of services by the user

Monetary freedom

Environmental problems

Quality of life
Dispute between producers of the same good or providers of a specific service that seek to serve the same target audience, often sharing the same location.

Refers to the usability and knowledge of technology and services in block chains.

Monetary freedom means freedom of currency choice; it also means freedom of currency production in an environment of free competition.

Refers to the negative effect that technology development has on the environment.

Refers to the benefits generated by technology and bitcoin currency, benefits that are directly linked to the proposed life improvement (health, poverty, agility, and less stress).

Table 10. Subdimensions of Bitcoin and Social Environment

Source: Research data (2021).

The next step was to investigate the importance of the different dimensions and subdimension for the interviewees. We classified the interviews content using all dimensions and subdimensions and evaluated the amount of contribution of each one in all interviewees. Dimensions results, presented in Table 11, are very similar, indicating that our sample discussed all the dimensions with a similar emphasis. We did not find any significant difference also among the subdimensions.

\begin{tabular}{cc}
\hline Dimensions & $\begin{array}{c}\text { \% of interviewees } \\
\text { content }\end{array}$ \\
\hline Bitcoin Business and Entrepreneurship & 25.2 \\
Bitcoin Technological Aspects & 25.1 \\
Bitcoin and Social Environment & 24.9 \\
Bitcoin Law and Regulation & 24.7 \\
\hline Total & 100.0 \\
\hline
\end{tabular}

Table 11. Group 2 - Interviewees with their respective activities

Source: Research data (2021)

\section{Bitcoin dimensions content}

The dimension with a slightest greater contribution is Business and Entrepreneurship, representing $25.2 \%$. Bitcoin is seen more than a new financial monetary system, there are several applications of this technology in the registration market, for example. Difficulties of competing with the other actors who were in the market and what their inspirations were, are examples of topics discussed. The current scenario was also present in this dimension, since the actors that have recently emerged are in diverse fields, like education in bitcoin, among others. 
Technological Aspects dimension contributed with $25.1 \%$ of the content. The concern with technology and its development was clear, since there are limitations regarding the technology, such as block size (ledger), processing time and validation of transactions, and amount of coins issued up to the moment versus the supply and demand of that currency. In general, the actors presented proposals for improvement and reported a very active search for the best experiences for the final customer.

Bitcoin and Social Environment dimension represented $24.9 \%$ and the sample talked about diverse aspects of the relationship between bitcoin and society. Law and Regulation dimension had $24,7 \%$ of the total content. The sample expressed concern with legal aspects for several reasons, among them, the security of being supported in some way by the government in the face of a problem that may happen, or even the greater usability of technology in the face of a future regulation of cryptocurrencies. The sample followed all the communications made by Bacen and regulations implemented in the outside world.

\section{Cluster analysis diagram}

Cluster analysis is an exploratory technique that allows the visualization of semantic patterns, grouping sources, or dimensions and subdimensions that share similar words/values/attributes. The more times the word was mentioned in the analyzed cases, the greater was the cluster size, the higher was the frequency and it had more visibility. This type of technique represents data distribution and focuses on data visualization.

Internal analysis of the dimension and subdimensions

The codification process created a system of subdimensions. The coding was based on the common characteristics of interview content. We conducted a cluster analysis (by NVivo) with subdimensions, and Figure 1 shows the results of the grouping of the subdimensions that emerged from the Pearson Correlation analysis of the transcripts of the interviews.

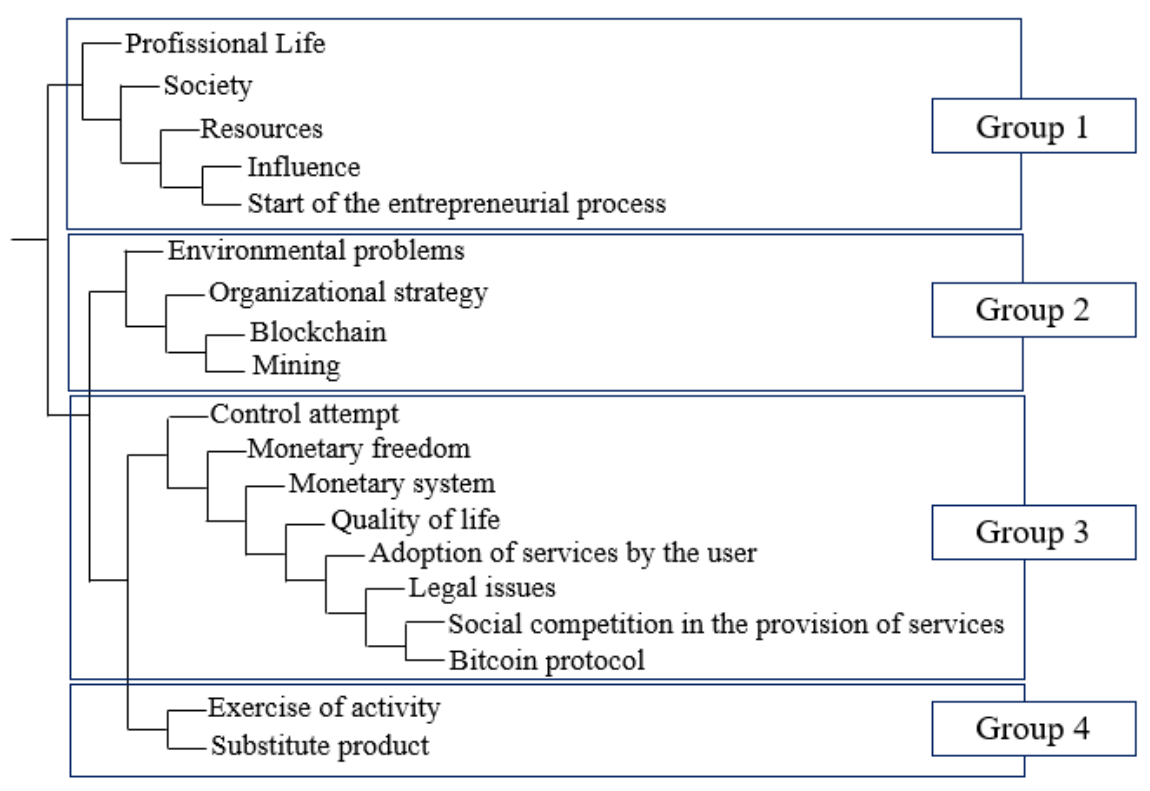

Figure 1. Grouping of subdimensions

Source: Research data (2021).

When looking at Figure 1, it appears that two large groups were formed: Group 1 has 5 of 7 subdimensions of the Bitcoin Business and Entrepreneurship Dimension (professional life, society, resources, influence, and beginning of the entrepreneurial process). The other three groups were connected between 
them and were more mixed. Group 2 was composed of 4 subdimensions from 3 different dimensions. Group 3 had 8 subdimensions also from 3 different dimensions. The last group, Group 4, had only 2 subdimensions from 2 dimensions.

Coefficients of all groups are high, and this shows how related the subdimensions are to the actors' perceptions, in general. From this, the group that presents the greatest approximation between the subcategories relating the proximity of words is Group 3 with .961, followed in decreasing order by Group 1 with .950, Group 2.938 , and finally, Group 4 with .904. The high similarity of the subdimensions is notorious because, among the relationships, only two gave a moderate positive (which is the second-highest measurement according to Pearson's picture); that is, the measurement among all related subdimensions is extremely high. This indicates that, in spite of the fact that each dimension relates with a specific aspect of bitcoin ecosystem, the dimensions are very connected,and with its respective subdimensions being interconnected.

The next analysis performed was to investigate the relationship of similarity between the interviewees. We conducted a cluster analysis, but no relevant groups were formed, indicating that, in spite of the differences between the interviewees regarding professional profiles, they share similar perceptions in the bitcoin dimensions and subdimensions.

\section{CONCLUSION}

This work had as general objective the mapping of bitcoin dimensions perceived by actors of the value chain of the bitcoin ecosystem. We also identified the key actors of this ecosystem in the Brazilian market and the challenges perceived by these actors in relation to the commercialization of bitcoin.

Even if bitcoin fails and disappears in the future, the underlying technology will stay with us and will continue to disrupt existing businesses and create new industries (Chen, 2018). Faced with this initial scenario of monetary freedom and the transformation of the monetary system, many countries around the world began to study bitcoin technology, to seek an understanding of what bitcoin is and the possible impacts caused if this disruptive innovation is used in a more intense way (Larios-Hernández, 2017). The market has expanded during the last years, showing that bitcoin technology, based on the blockchain protocol, can be use by different kinds of organizations, and not only the ones in the financial sector. This technology allows the transparency of information of all nodes (users) that are in this decentralized network (Lee, 2019).

Brazil has several users of the decentralized network, as well as individuals who bet on this innovation as a means of investment or form of payment, believing in the growth of bitcoin market in the country. Also, financial institutions, as well as other commercial institutions, are looking for ways to apply bitcoin technology to their businesses.

At the same time, many organizations have businesses that are threatened by bitcoin technology, as the case of the notaries and companies that use archaic forms of patents, or even financial institutions that are losing market share for startups and FinTechs. These markets segments need to react, that is, get quick answers to their consumers, before they are eliminated by the competitive advantage of these digital technology companies.

This research is a preliminary attempt to advance research on bitcoin in the country, since there are few works, and articles published on this topic. The interviews, carried out with the most recognized actors of the bitcoin segment in the country, provided a solid and reliable contextualization of the Brazilian bitcoin scenario.

The study mapped the main dimensions that converged within the context of the Brazilian bitcoin scenario: Business and Entrepreneurship, Technological Aspects, Law and Regulation, and Social Environment. The mapping of bitcoin dimensions indicated that dimensions have similar relevance for the main actors of bitcoin network.

It is important to highlight that the sample interviewed expressed an embracing vision of bitcoin network and a very proactive behavior regarding information seeking and technology development. They mentioned main players, challenges and reported on how financial institutions are trying to adapt to the new 
technology, a technology that is disruptive and generates many doubts regarding issues of trust in the data transaction.

\section{REFERENCES}

Albuquerque, B. S. de, \& Callado, M. C. (2015). Understanding Bitcoins: Facts and Questions. Revista Brasileira de Economia, 69(1), 03-16.

Andrade, M. D. (2017). Tratamento jurídico das criptomoedas: a dinâmica dos bitcoins e o crime de lavagem de dinheiro. Revista Brasileira de Políticas Públicas, 7(3), 44-59.

Blau, B. M. (2018). Price dynamics and speculative trading in Bitcoin. Research in International Business and Finance, 43(issue C), 15-21.

Câmara dos Deputados (2015a). Projeto de Lei 48/2015. Extingui a produção, circulação e uso do dinheiro em espécie, e determina que as transações financeiras se realizem apenas através do sistema digital. Retrieved from http://www.camara.gov.br/proposicoesWeb/prop_mostrarintegra;jsessionid=CD7E7C41D7D07387C79C1 70C93D385D2.proposicoesWebExterno1? codteor $=1296773 \&$ filename $=P L+48 / 2015$

Câmara dos Deputados (2015b). Projeto de Lei 2303/2015 - Projeto de Lei. Retrieved from http://www.camara.gov.br/proposicoesWeb/fichadetramitacao?idProposicao=1555470

Câmara dos Deputados (2017). Projeto de Lei 2303/10. Inclusão das moedas virtuais e programas de milhagem aéreas na definição de "arranjos de pagamento" sob a supervisão do Banco Central. Retrieved from http://www.camara.gov.br/proposicoesWeb/prop_mostrarintegra;jsessionid=DD5E05FAE78BFD7EB197A 4E826A9DFFA.proposicoesWebExterno1?codteor=1358969\&filename $=P L+2303 / 20>15$

Chen, Y. (2018). Blockchain tokens and the potential democratization of entrepreneurship and innovation. Business Horizons, 61(4), 567-575. https://doi.org/10.1016/j.bushor.2018.03.006

Corbet, S., Lucey, B., Urquhart, A., \& Yarovaya, L. (2019). Cryptocurrencies as a financial asset: A systematic analysis. International Review of Financial Analysis, 62, 182-199. https://doi.org/10.1016/j.irfa.2018.09.003

Diedrich, H. (2016). Ethereum: Blockchains, digital assets, smart contracts, decentralized autonomous organizations. Middle- town, DE: Wildfire Publishing.

Dwyer, G. P. (2015). The economics of Bitcoin and similar private digital currencies. Journal of Financial Stability, 17, 81-91. https://doi.org/10.1016/j.jfs.2014.11.006

Crosby, M., Nachiappan, Pattanayak, P., Verma, S., Kalyyanaraman. (2016). BlockChain Technology: Beyond Bitcoin. Applied Innovation Review, 2, 6-19.

Feraru, G. M. (2017). Corporate entrepreneurship as a mechanism to turn innovation into competitive advantage. Annals - Economy Series, Constantin Brancusi University, Faculty of Economics, 1, 213-219.

Filion, L. J. (1999). Diferenças entre sistemas gerenciais de empreendedores e operadores de pequenos negócios. Revista de Administração de Empresas, 39(4), 6-20.

Henderson, B. D. (1989). The origin of strategy. Harvard Business Review, 67(6), 139-144.

Kelly, M. (2013). Fool Me Once: Bitcoin Exchange Mt.Gox Falls after Third DDoS Attack This Month. VentureBeat. Retrieved from http://venturebeat.com/2013/04/21/mt-gox-ddos/

Lage, M. C. \& Godoy, A. S. (2011). Utilização do software NVivo e na pesquisa qualitativa: uma experiência em EAD. ETD - Educação Temática Digital, 12(esp.), 198-226.

Larios-Hernández, G. J. (2017). Blockchain entrepreneurship opportunity in the practices of the unbanked. Business Horizons, 60(6), 865-874.

Lee, J. Y. (2019). A decentralized token economy: How blockchain and cryptocurrency can revolutionize business. Business Horizons, 62(6), 773-784. 
Lyócsa, Š., Molnár, P., Plíhal, T., \& Širaňová, M. (2020). Impact of macroeconomic news, regulation and hacking exchange markets on the volatility of bitcoin. Journal of Economic Dynamics and Control, 119, 103980.

Roberto, E., Horta, L. S. R., Luz, L. F. B., \& Monteiro, R. L. (2017). A regulação de ICOs e criptomoedas no Brasil. White paper, 1-15. Retrieved from http://baptistaluz.com.br/wp-content/uploads/2017/11/ICOs-eBitcoins.pdf

Min, H. (2019). Blockchain technology for enhancing supply chain resilience. Business Horizons, 62(1), 35-45. https://doi.org/10.1016/j.bushor.2018.08.012

Nakamoto, S. (2008). Bitcoin: A Peer-to-Peer Electronic Cash System. Bitcoin Org. Retrieved from https://bitcoin.org/bitcoin.pdf

Pires, H. F. (2018). Bitcoin: a moeda do ciberespaço. Geousp - Espaço e Tempo, 21(2), 407-424.

Scharding, T. (2019). Is Bitcoin Trustworthy? In J. J. Choi, \& B. Ozkan (Eds.) Disruptive Innovation in Business and Finance in the Digital World. International Finance Review, 20, 151-165.

Scott, B., Loonam, J., \& Kumar, V. (2017). Exploring the rise of blockchain technology: Towards distributed collaborative organizations. Strategic Change, 26(5), 423-428.

Shynkevich, A. (2020). Bitcoin Futures, Technical Analysis and Return Predictability in Bitcoin Prices. Journal of Forecasting, 40(4), 730-730.

Stegaroiu, C-E. (2017). Bitcoin - The Currency of a new economy? Annals - Economy Series, Constantin Brancusi University. Faculty of Economy, 2, 114-119.

Tumelero, C., Sbragia, R., Borini, F. M., \& Franco, E. C. (2018). The role of networks in technological capability: a technology-based companies perspective. Journal of Global Entrepreneurship Research, 8(1), 1-19.

Vinuto, J. (2014). A amostragem em bola de neve na pesquisa qualitativa: um debate em aberto. Temáticas, $22(44), 201-218$. 